\title{
Risk Assessment and Clinical Risk Management for Young Antisocial Children: The Forgotten Group
}

\section{Evaluación del riesgo y manejo del riesgo clínico en jóvenes antisociales: el grupo olvidado}

Recibido: febrero 8 de 2012 | Revisado: mayo 8 de 2012 | Aceptado: julio 5 de 2012

\author{
LEENA AUGIMERI* \\ MARGARET WALSH ** \\ SARAH WOODS *** \\ Child Development Institute, Toronto, Canada \\ DEPENG JIANG $* * * *$ \\ University of Manitoba, Winnipeg, Canada
}

SICI: 1657-9267(201212)11:4<1147:RACRMY>2.0TX:2-9

Para citar este artículo: Augimeri, L., Walsh, M., Woods, S. \& Jiang, D. (2012). Risk Assessment and Clinical Risk Management for Young Antisocial Children: The forgotten group. Universitas Psychologica, 11(4), 1147-1156.

Email: laugimeri@childdevelop.ca. ResearcherID: Augimeri, L., H-2729-2012

*** Email: mwalsh@childdevelop.ca. ResearcherID: Walsh, M., H-2731-2012

**** Email: swoods@childdevelop.ca. ResearcherID: Woods, S., H-2681-2012

***** Email: Depeng.Jiang@med.umanitoba.ca. ResearcherID: Depeng, J. H-2955-2012

\section{A B S T R A C T}

Centre for Children Committing Offences (CCCO), at Child Development Institute (CDI) in Toronto, Canada, developed Early Assessment Risk Lists (EARL-20B for boys; EARL-21G for girls), for young children at-risk for future criminality. In this first EARL prospective longitudinal study, 573 boys and 294 girls who participated in $\mathrm{SNAP}^{\circledR}$, a gender-specific evidencebased model for at-risk children (6-11 years), $8.2 \%$ of boys and $3.1 \%$ of girls had registered criminal offences at follow up (mean age 14.9 and 14.6 respectively). EARL Total, Family, Child, and Responsivity domain scores, including two gender-specific risk items and Overall Clinical Judgment predicted early onset of criminal activity. Findings suggest that gender-sensitive clinical risk assessment and management tools are important for effectively identifying and potentially reducing criminal outcomes.

Key words authors

Centre for Children Committing Offences, Child Development Institute, Early

Assessment Risk Lists, Criminality

Key words plus

Gender-specific Evidence-based Model, Justice Juvenile, Child

\section{RESUMEN}

En el Centro para Niños Infractores (CCCO), del Instituto de Desarrollo Infantil (CDI) en Toronto (Canadá), se desarrollaron las Listas de Evaluación de Riesgos Tempranos (EARL-20B para niños; EARL-21G para niñas), para niños en riesgo de desarrollar criminalidad. En este primer estudio longitudinal de las EARL, 573 niños y 294 niñas que participaron en SNAP, un modelo basado en evidencia de género específico para riesgo en niños (6-11 años), $8.2 \%$ de niños y $3.1 \%$ de las niñas registraron delitos criminales durante el seguimiento $(M=14.9$ y 14.6 , respectivamente). Los puntajes de EARL Total, Familia, Niños y Responsividad, incluyendo dos ítems de riesgo específicos de género, y el Juicio Clínico General predicen el inicio temprano de actividad criminal. Los resultados sugieren que la evaluación del riesgo clínico sensible al género y el manejo de herramientas son importantes para la identificación efectiva y potencialmente reducen los resultados criminales.

Palabras clave autores

Centro para niños infractores, Instituto de desarrollo infantil, Listas de Evaluación de Riesgos Tempranos, criminalidad.

Palabras clave descriptores

Modelo basado en evidencia de género, Justicia Juvenil, niños. 
Healthy child development, crime prevention/ intervention funding and research are often directed towards children under the age of six and/ or adolescents. Young latency-aged children (6-11 years of age) in contact with the law are typically forgotten partly due to their small numbers and minor offences (Snyder, Espiritu, Huizinga, Loeber, \& Petechuck, 2003). Recent research highlights "seven years of warning" before a juvenile becomes a serious, violent offender. Youth appearing in court for a serious offence at age 15 began having minor difficulties as early as age six, moderate problems by age nine, and began engaging in serious, delinquent behaviour prior to their twelfth birthday (Loeber, Farrington, \& Petechuk, 2003).

Moffitt (1993) highlighted two developmental pathways to antisocial behaviour. Children on the Life Course Persistent (LCP) pathway exhibit antisocial behaviours at a very early age and are at risk for continued involvement. Youth on the Adolescent Limited (AL) pathway begin their antisocial behaviour in adolescence but typically desist once they enter young adulthood. Odgers et al., (2007) identified a third pathway, Childhood Limited $(\mathrm{CL})$, where children engage in antisocial behavior at a very early age but desist as they get older. As evidenced by this research, many children show variability and desistance over time (Lipman, Bennett, Racine, Muzumdar \& Offord, 1998) making it difficult to predict which children will continue or discontinue with their antisocial behaviour.

Rigorous research has been conducted on risk factors contributing to antisocial behavior and the various trajectories (e.g., Howell, 2003; Lahey, Moffitt \& Caspi, 2003) resulting in a comprehensive understanding that early risk factors, nested within family, individual child, neighbourhood, school and peer domains, place antisocial children at "risk" for engaging in future delinquency and offending (Loeber, Slot \& Stouthamer-Loeber, 2008). The introduction of the structured professional judgment (SPJ) approach to risk assessment has resulted in the development of a systematic method to assess and manage risk, bridging the gap between science and practice. SPJ relies on clinical expertise, clinical application and descrip- tions of evidence-based risk factors that relate to antisocial behaviours and change over time. SPJ tools have been developed for use with adults (e.g, Historical, Clinical, Risk Management-20 [HCR20]; Webster, Douglas, Eaves \& Hart, 1997) and youth (e.g., Structured Assessment of Violence Risk in Youth [SAVRY] Borum, Bartel \& Forth, 2002) advancing both correctional and forensic mental health systems of care (Bloom, Webster, Hucker \& DeFreitas, 2005; Webster, Martin, Brink, Nicholls \& Middleton, 2004). However, prior to 1998 , there were no assessment schemes available to identify specific domains of risk for antisocial children under the age of 12 (Augimeri, Koegl, Ferrante \& Slater, 2006; Hrynkiw-Augimeri, 2005).

Predicting which antisocial child will continue to engage in such behaviour in adolescence and/or adulthood is one of the most important challenges in the field of developmental criminology. Addressing this challenge and the gap in risk assessment tools, the Centre for Children Committing Offences (CCCO) housed at Child Development Institute (CDI) in Toronto, Canada developed a comprehensive psychosocial risk assessment framework specifically focused on young children with antisocial problems who may have also been in trouble with the law (Augimeri, Walsh, Liddon \& Dassinger, 2011; Borum et al., 2002; Koegl, Augimeri, Ferrante, Walsh \& Slater, 2008). This framework includes: (1) police-community referral protocols; (2) risk assessment tools; and (3) genderspecific evidence-based programs that target emotional regulation and self-control. The long-term goal of this framework is to prevent young children from criminal contact with the youth justice system or, at the very least, delay their entry as long as possible and to avoid following a LCP trajectory.

The risk assessment tools Early Assessment Risk List (EARL-20B) for boys (Augimeri, Koegl, Webster \& Levene, 2001) and EARL-21G for girls (Levene et al., 2001) were developed under this framework. Initially, the tools were designed to assist in risk identification and clinical risk management for the evidence-based SNAP ${ }^{\circledR}$ (STOP NOW AND PLAN) model. The SNAP ${ }^{\circledR}$ model provides a framework for effectively teaching chil- 
dren and their parents' self control and problem solving skills. The SNAP ${ }^{\circledR}$ Boys and SNAP ${ }^{\circledR}$ Girls programs serve children ages $6-11$, who are clinically assessed as engaging in high levels of aggressive, and/or oppositional behaviours such as stealing, lying, aggression and bullying. Typical referral sources are schools, child welfare, police, fire service, and parents. SNAP ${ }^{\circledR}$ employs a multi-systemic approach, combining interventions that target the child, the family, the school, and the community. The program includes nine unique service components based on level of risk and need including, SNAP ${ }^{\circledR}$ Boys or Girls Group, a concurrent SNAP ${ }^{\circledR}$ Parent Group, Individual Befriending/Mentoring, and Stop Now and Plan Parenting (SNAPP) and Individualized Family Counseling (see www.stopnowandplan.com and Augimeri, Walsh \& Slater, 2011, for details on evaluation findings and model implementation). The EARLs are a part of the program's screening and assessment procedures to determine the differential treatment needs of children and their families and assists clinicians with treatment planning. Gender-sensitivity was employed in response to researchers (e.g., Moffit, Caspi, Rutter \& Silva, 2001) recognizing that although antisocial boys and girls present with similar levels of problem behaviour, the presentation of these behaviours and future outcomes may vary partly due to gender issues.

Previous retrospective SNAP ${ }^{\circledR}$ case file studies that investigated the predictive validity of the EARLs on criminal outcome were positive. Augimeri, Desmarais, Koegl, Jiang and Webster (2009) found that mean EARL-20B total scores of boys who were found guilty of an offence were significantly higher than for those boys who were not found guilty of an offence. These authors also found higher total scores postdicting findings of guilt at levels greater than expected by chance. Enebrink, Långström, Hultén and Gumpert (2006) found the EARL-20B showed good predictive validity for parent and teacher ratings of reactive and proactive aggression at six and 30-month follow-up. Using a retrospective longitudinal design, Koegl (2011) found the EARL total score significantly predicted prevalence of crime for both males and females. The total score also predicted frequency of convictions and membership in high-risk offending groups for males. Studies on the EARL-21G produced similar positive findings for clinical utility, reliability and validity of the tool (Levene, Walsh, Augimeri \& Pepler, 2004; Walsh, Yuile, Jiang, Augimeri \& Pepler, 2007).

\section{Current Study}

The primary focus of our analyses was to further examine the clinical utility of the EARLs for identifying those children who are most at-risk for "flipping" into the criminal justice system. This prospective study design used clinician rated EARLs to predict criminal outcome. As the EARLs have previously shown to have good predictive validity within retrospective case file study design, we hypothesized that clinician-rated assessment of risk will significantly predict criminal outcome. Furthermore, these clinician rated EARLs will help to identify the children most at-risk for early onset of offending. As well, we would expect that various individual risk items and/ or the domains (i.e., Family, Child and Responsivity) will add to the predictive validity of the EARLs. We also hypothesized there will be significant differences between gender on prevalence and probability of criminal outcome.

\section{Method}

\section{Participants}

The sample was derived from clients who participated in SNAP ${ }^{\circledR}$ at two multi-service organizations: $\mathrm{CDI}$ in Toronto and Banyan Community Services (BCS) in Hamilton, Ontario. All participants were in the programs between 2001 to 2009 and met the following admission criteria: a) 6 to 11 years of age; b) scored in the clinical range on the externalizing or conduct subscales using a standardized behavioural assessment; or c) police contact. Children were excluded from the program if they demonstrated a significant developmental delay.

After excluding those with missing date of birth $(\mathrm{N}=34)$ and younger than 12 by December 31 , 
2009 ( $N=406)$, data from the remaining 867 participants $(N=524$ for $\mathrm{BCS} ; \mathrm{N}=343$ for $\mathrm{CDI})$ were used for the analysis of risk of future offense. The sample included 573 boys and 294 girls. The mean age at referral was 10.4 for boys and 9.5 for girls. At the time of criminal record retrieval, the age ranged from 12 to 20 for boys, with mean age of 14.9; the age ranged from 12 to 19 for girls with a mean age of 14.6.

\section{Measures}

\section{Early Assessment Risk List for Boys} (EARL-20B) and Girls (EARL-21G)

The EARL-20B and EARL-21G items are scored on a three point scale: 0 not present; 1 somewhat present; and 2 present. Total scores are then summed across the Family, Child, and Responsivity domains to represent the total level of risk the child currently experiences in his or her life. Family items assess the extent to which the child has or has not been effectively nurtured, supported, supervised, and encouraged by their parents or caregivers. Child items focus on individual risk factors associated with the child and the extent to which they perform his/her social role and acts responsibly and sensibly. Responsivity focuses on the ability and willingness of both the child and family to engage in treatment and to benefit from planned interventions. The EARL$21 \mathrm{G}$ closely parallels the EARL-20B: two distinct items (Caregiver-Daughter Interaction and Sexual Development) were added, and one item was removed (Authority Contact was subsumed under Antisocial Behaviour) to yield a 21-item tool for girls. The EARLs also include an Overall Clinical Judgment Rating, allowing clinicians to render a low, moderate or high risk designation regardless of the total score.

EARL assessments were scored in accordance to instructions described in their respective manuals. Previous EARL-20B research studies have included findings on the tools' reliability and validity. Reliability scores on the total EARL-20B score values showed acceptable mean inter-rater reliability (e.g., $M=0.92$; Enebrink, Långström \& Gumpert, 2006).

\section{Criminal Record Data}

The data was obtained through a court order and under a section of the Youth Criminal Justice Act (YCJA) and the Ministry of Children and Youth Services (MYCS) that allow retrieval of data for research purposes. For the purpose of this paper the following outcome variables were used: (a) charged with a criminal offence -yes/no; and (b) the age of onset.

\section{Procedures}

During admission to services, caregivers are asked to sign a standard treatment and research consent form. Within the consent the caregivers are informed that their personal information is used first and foremost for treatment planning purposes and will remain confidential, unless required by law. If used for a secondary purpose, such as program evaluation and/or research, the information will be coded numerically and de-identified prior to being analyzed. Moreover, no identifying information would be included in publications or materials released from the institute. At admission, clinicians trained on the EARLs complete the risk assessment as part of their eco-systemic review and before treatment. To be selected for the study analyses, participants were required to have had a clinicianrated EARL assessment and to be 12 years of age by December, 2009.

\section{Results}

Cox regression was used to analyze if and when a criminal offence occurred and whether the EARL20B and EARL-21G tools predict criminal offending. Cox Regression builds a predictive model for time-to-event data which incorporates all participants (those with and without criminal offence by the time criminal data were retrieved) into analyses. The shape of the survival function and the regression coefficients for the predictors are esti- 
TABLE 1

Descriptive Statistics of 111 Criminal Offences

\begin{tabular}{|c|c|c|}
\hline Characteristics & $\begin{array}{c}\text { Boys } \\
(N=47) \\
N\end{array}$ & $\begin{array}{c}\text { Girls } \\
(N=9) \\
N\end{array}$ \\
\hline Mean (median, min-max) age at offence & $14.4(14.2,12-18)$ & $14.2(14.8,12-16)$ \\
\hline Total Number of Offences & 97 & 14 \\
\hline \multicolumn{3}{|l|}{ Number of offences } \\
\hline 1 & 41 & 6 \\
\hline 2 & 28 & 4 \\
\hline More than 2 & 28 & 4 \\
\hline \multicolumn{3}{|l|}{ Number of convictions } \\
\hline 1 & 18 & 2 \\
\hline 0 & 79 & 12 \\
\hline Number of multiple sentences & $67(69.1 \%)$ & $7(50.0 \%)$ \\
\hline \multicolumn{3}{|l|}{ Type of Offence } \\
\hline Assault & 39 & 8 \\
\hline Robbery & 16 & 1 \\
\hline Breaking and entering & 7 & 1 \\
\hline Theft & 19 & 3 \\
\hline Weapon & 14 & 3 \\
\hline Fraud & 2 & 0 \\
\hline Mischief & 20 & 4 \\
\hline Drug & 16 & 2 \\
\hline
\end{tabular}

Source: own work.

mated from observed subjects; the model can then be applied to new cases that have measurements for the predictor variables. Note that information from those that do not have a criminal offence, contributes to the estimation of the model. A series of Cox regression models were fitted to examine how individual EARL items, EARL subtotals, and EARL total scores associated with the risk of criminal offences on the combined sample of boys and girls. Due to the small sample size of girls with criminal offences $(N=9)$ separate analysis for gender were not conducted except for those gender-specific EARL items (e.g., Caregiver-Daughter Interaction and Sexual Development).

The mean age of first offence for boys was 14.8 $(\mathrm{SD}=1.6$; range: $12-18)$ and for girls was very low at $14.2(\mathrm{SD}=1.2$; range: $12-16)$. The boys had a higher mean number of offences than girls $(0.35$, $S D=1.92$, range: 0.26 vs. $0.10, S D=0.74$, range: $0-11)$. The mean number of presenting problems for boys was 3.4 ( $S D=2.5$; range: $0-14$ ) and for girls was $3.2(S D=1.8$; range: $1-11)$. Forty-seven $(8.2 \%)$ out of 573 boys and 9 (3.1\%) out of 294 girls had one or more registered offences resulting in a total of 111 criminal records. Descriptive statistics for the 111 participants charged with a criminal offence are presented in Table 1.

Table 2 presents results for unadjusted hazard ratios for the risk of criminal offences from the univariate Cox regression models. It is common that hazard ratios are reported in Cox regression instead of odds ratios as in the regular logistic regression. Hazard ratios differ from odds ratios in that the latter are cumulative over an entire study, using a defined endpoint, while the former represent instantaneous risk over the study time period, or some subset thereof. Hazard ratios suffer somewhat less from selection bias with respect to the endpoints chosen, and can indicate risks that happen before the endpoint.

Results indicate that the increase of probability of levels of risk was associated with an increased 
TABLE 2

Results of fitting Cox regression models for factors associated with criminal offences

\begin{tabular}{|c|c|c|}
\hline Variable & $\begin{array}{c}\text { Crude Hazard Ratios } \\
(95 \% \mathrm{CI})\end{array}$ & p-value \\
\hline Family Item Total & $1.14(1.03-1.27)$ & 0.01 \\
\hline F1 Household Circumstances & $1.54(1.06-2.25)$ & 0.02 \\
\hline F2 Caregiver Continuity & $1.35(0.95-1.93)$ & 0.09 \\
\hline F3 Supports & $1.56(1.05-2.32)$ & 0.03 \\
\hline F4 Stressors & $1.11(0.75-1.65)$ & 0.61 \\
\hline F5 Parenting Style & $2.17(1.37-3.44)$ & $<0.001$ \\
\hline F6 Antisocial Values \& Conduct & $1.12(0.83-1.53)$ & 0.45 \\
\hline Caregiver-Daughter Interaction (Girls Only) & $2.06(0.68-6.21)$ & 0.20 \\
\hline Child Item Total & $1.09(1.02-1.17)$ & 0.01 \\
\hline C1 Developmental Problems & $0.77(0.46-1.30)$ & 0.32 \\
\hline C2 Onset of Behavioural Difficulties & $0.54(0.34-0.84)$ & 0.01 \\
\hline C3 Trauma & $1.06(0.78-1.45)$ & 0.72 \\
\hline C4 Impulsivity & $0.89(0.63-1.24)$ & 0.47 \\
\hline C5 Likeability & $1.43(0.96-2.13)$ & $0.07 *$ \\
\hline C6 Peer Socialization & $1.68(1.11-2.55)$ & 0.02 \\
\hline C7 School Functioning & $1.13(0.80-1.59)$ & 0.51 \\
\hline C8 Neighborhood & $1.23(0.89-1.71)$ & 0.21 \\
\hline C9 Police Contact For Boys and Sexual Development for Girls & $2.51(1.73-3.64)$ & $<0.001$ \\
\hline C10 Antisocial Attitudes & $3.13(1.84-5.33)$ & $<0.001$ \\
\hline C11 Antisocial Behaviour & $2.07(1.19-3.60)$ & 0.01 \\
\hline C12 Coping Ability & $0.87(0.59-1.28)$ & 0.47 \\
\hline Responsivity & $1.50(1.19-1.89)$ & $<0.001$ \\
\hline A1 Family Responsivity & $2.14(1.49-3.07)$ & $<0.001$ \\
\hline A2 Child Responsivity & $1.33(0.91-1.95)$ & 0.15 \\
\hline EARL Total Score & $1.09(1.04-1.15)$ & $<0.001$ \\
\hline Overall Clinical judgment & $2.75(1.45-5.21)$ & $<0.002$ \\
\hline
\end{tabular}

Note: * To account for different items in the instrument, we created a total EARL score with 19 common items across the two instruments, the conclusion (hazard ratios $=1.08$ (95\% CI: 1.00-1.16), $p$-value $=0.05$ ) are similar with using total EARL score of all items ( 20 for boys and 21 for girls).

Source: own work.

risk of future criminal offences for the following domains/risk items: Family Domain (Household Circumstances, Supports, Parenting Style), Child Domain (Onset of behavioral difficulty, Peer Socialization, Antisocial attitudes, Antisocial Behaviour, Police Contact For Boys and Sexual Development for Girls), Responsivity Domain (Family Responsivity). EARL total score and each domain subtotal score were also significantly associated with an increased risk of registering a criminal conviction. For each 1-point increase in total EARL score, the estimated hazard of future offences was 1.09 times (95\% Confidence Interval: 1.04-1.15) that for children with 1 score lower of EARL score.

Overall Clinical Judgment also predicted the probability of a being charged with a criminal offence. Among the 38 low risk (clinical judgment) children, no child had a criminal offence, whereas 11 out of $222(5.0 \%)$ moderate risk children and 36 out of 308 (11.7\%) high risk children had a criminal offence. The Overall Clinical Judgment was also highly correlated with the total EARL score (Spearman correlation $=0.66, p<0.0001$ ). 


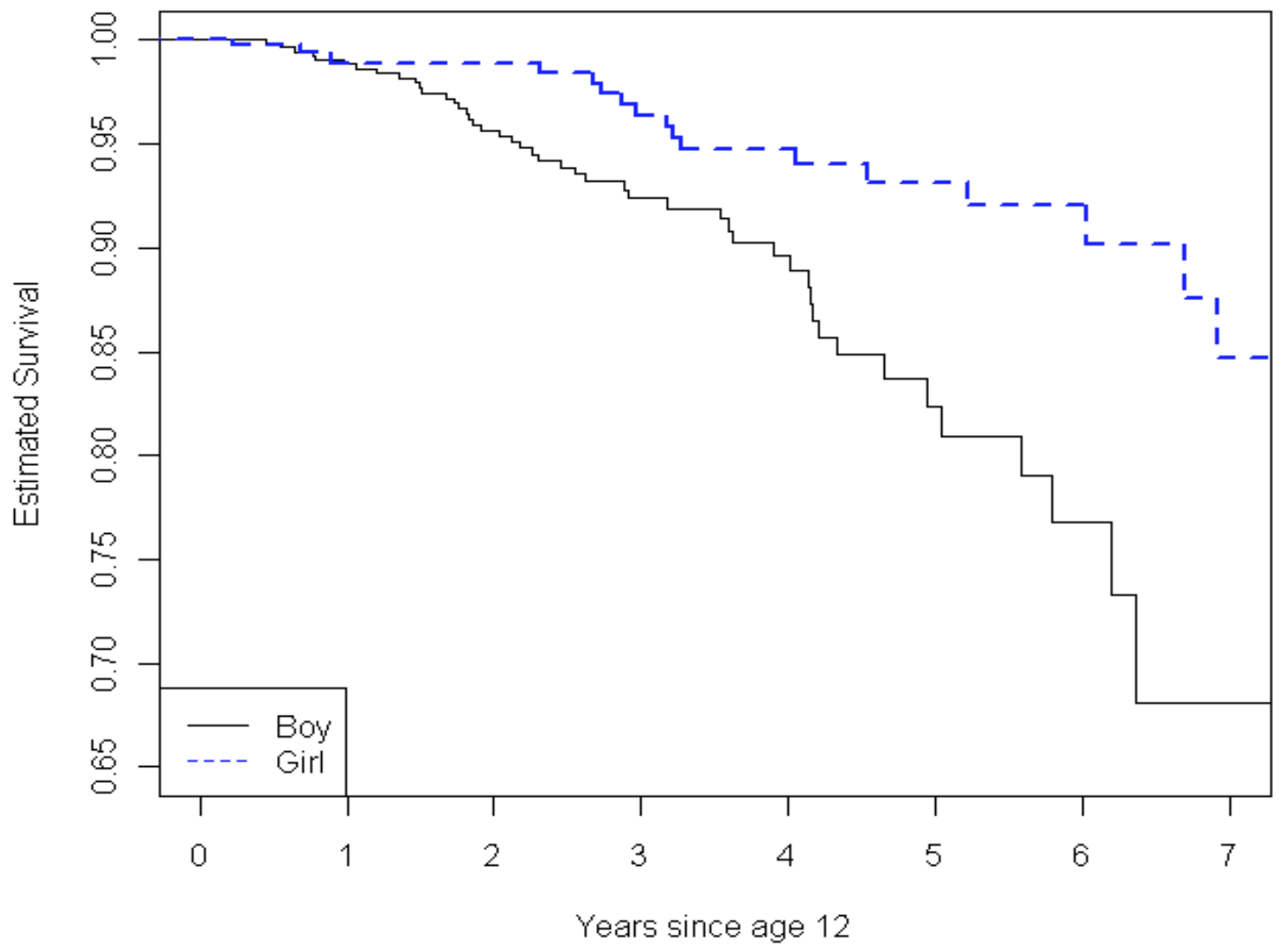

Figure 1. Kaplan-Meier Survival Curve $(\mathrm{N}=867)$.

Source: own work.

Log-rank tests indicated there is a significant gender difference in the risk of criminal offence and onset age of criminal offence $\left(\chi^{2}=6.64\right.$ with degrees of freedom of $1, p=0.01)$. Figure 1 shows the estimated Kaplan-Meier survival curve separated by boys and girls. Cox regression analysis indicated that the hazard of criminal offence for boys is 2.5 times $(95 \%$ CI: $1.4-4.3 ; p=0.001)$ than that of girls. These results revealed that boys are at higher risk for a criminal offence than girls. It is also estimated that by age 19 , approximately $32 \%$ of the boys may have a criminal conviction. The girls' sample, however, is too small to make any conclusions.

Ideally, we should conduct multivariable analyses to test factors associated with the risk of future criminal offence and the relationship between EARL items, gender, and risk of criminal offence.
However, the small sample size (only 47 of 573 boys and 9 of 294 girls) makes the multivariable analysis inappropriate for our sample.

\section{Discussion}

The purpose of the current study was to examine the predictive validity of the EARLs using a combined prospective sample from two $\mathrm{SNAP}^{\circledR}$ sites in Ontario. For the 573 boys (14.9 mean age at followup; range $12-20$ years) and 294 girls (14.6 mean age at follow up; range 12-19 years), criminal record data retrieved showed that $8.2 \%$ of boys and 3.1\% of girls had one or more criminal offences. It was estimated that by age 19 , a large majority $(68 \%)$ of these boys will not have criminal justice contact. Survival Curve analysis also showed that boys are 2.5 times more likely to enter the criminal justice 
system than the girls. Findings indicated the age of first offence for boys was 14.8. As noted in the introduction, this clinical sample of children is at significant risk of continued serious antisocial behaviour. A recent report highlighted that $85 \%$ of boys who have police contact before the age of 12 have a greater probability of continuing on this trajectory (Canfield \& Burke, 2011). Given the potential risk for this study sample to enter the juvenile justice system, early results indicate there is almost a three year gap in these children "flipping" into the juvenile justice system.

Furthermore, findings showed that the EARL Total score as well as the Family, Child and Responsivity domain scores, were accurate in predicting this early onset of criminal activity. As well, several individual risk items predicted future criminal activity (i.e., Household Circumstances, Supports, Parenting Style, Onset of Behavioural Difficulties, Peer Socialization, Antisocial Attitudes, Antisocial Behaviour) with Likeability showing a trend. Two unique gender-specific risk items, Authority Contact for boys and Sexual Development for girls, also predicted criminal contact. The Overall Clinical Judgment Rating predicted criminal outcome and was highly correlated to the Total EARL Score. It appears that the EARLs are 'decision enhancing/ aid’ tools (Enebrink, Långström \& Gumpert, 2006) that structure client information to help clinicians effectively render an accurate and informed professional judgment regarding risk and need.

\section{Study Limitations}

There are some notable limitations to the current study that should be discussed. Although the sample was large $(N=867)$ the mean age of the children for criminal outcome data retrieval was low (14.9 years of age for boys and 14.6 years of age for girls). This limited our ability to make any conclusive statements at this point about this young cohort in a longitudinal follow-up study design. We need to continue to follow these children until adulthood to be able to make any conclusive statements about long-term treatment sustainability, risk and trajectories.
Another limitation to consider has to do with using longitudinal data. Although training and consultation was available, there was no standard mechanism in place during the study time period to monitor and assess the quality of the EARLs.

\section{Future Research}

Continued follow-up of these children until adulthood is warranted. Further analyses are required to continue to investigate differences and similarities between genders in terms of aggression and childhood delinquency. Research has only recently started to investigate the area of promotive factors (e.g., Howell, 2003; Loeber et al., 2008) and future studies are needed to establish a greater understanding of promotive and protective factors, while also deciding on the importance of incorporating them into subsequent versions of the EARLs.

\section{Conclusion}

The study results have shown the EARLs have the ability to identity children at risk for future aggressive and delinquent behavior, and in addition, have clinical utility. These specialized gender specific tools assist clinicians in identifying and matching the level of risk and need to intensity of treatment and also help to facilitate discharge planning. Addressing the many risks/need of these children is vital in supporting them to stay in school and out of trouble, creating safer communities and healthier children and families.

\section{References}

Augimeri, L. K., Desmarais, S. L., Koegl, C. J., Jiang, D. \& Webster, C. D. (2009). Assessing risk for antisocial conduct among young children: Psychometric properties of the Early Assessment Risk List for Boys (EARL-20B). Unpublished manuscript.

Augimeri, L. K., Koegl, C. J., Ferrante, P. \& Slater, N. (2006). Why and how: Conducting effective clinical risk assessments with children with conduct problems. Canada's Children, 12(2), 24-27. 
Augimeri, L. K., Koegl, C. J., Webster, C. D. \& Levene, K. (2001). Early assessment risk list for boys: EARL20B. Version 2. Toronto, ON: Child Development Institute.

Augimeri, L. K., Walsh, M. M., Liddon, A. D. \& Dassinger, C. R. (2011). From risk identification to risk management: A comprehensive strategy for young children engaged in antisocial behavior. In D. W. Springer \& A. Roberts (Eds.), Juvenile Justice and delinquency (pp. 117-140). Sadbury, MA: Jones \& Bartlett.

Augimeri, L. K., Walsh, M. \& Slater, N. (2011). Rolling out SNAP® an evidence-based intervention: A summary of implementation, evaluation and research. International Journal of Child, Youth and Family Studies, 2(1), 162-184.

Bloom, H., Webster, C. D., Hucker, S. J. \& DeFreitas, K. (2005). The Canadian contribution to risk assessment: History and implications for current psychiatric practice. Canadian Journal of Psychiatry, 50(1), 3-11.

Borum, R., Bartel, P. \& Forth, A. (2002). Manual for the Structured Assessment of Violence Risk in Youth (SAVRY). Version 1. Tampa, Fl: University of South Florida.

Canfield, T. \& Burke, J. (2011, June). Two-year demonstration of SNAP (Pittsburgh report). Pittsburgh, PA: Pittsburgh Steering Committee.

Enebrink, P., Långström, N. \& Gumpert, C. H. (2006). Predicting aggressive and disruptive behavior in referred 6- to 12-year-old boys: Prospective validation of the EARL-20B Risk/Needs Checklist. Assessment, 13(3), 356-367.

Enebrink, P., Långström, N., Hultén, A. \& Gumpert, C. H. (2006). Swedish validation of the Early Assessment Risk List for Boys (EARL-20B), a decision-aid for use with children presenting with conduct-disordered behavior. Nordic Journal of Psychiatry, 60(6), 468-446.

Howell, J. C. (2003). Preventing and reducing juvenile delinquency: A comprehensive framework. Thousand Oaks, CA: Sage.

Hrynkiw-Augimeri, L. K., (2005). Aggressive and antisocial young children: Risk assessment and management utilizing the Early Assessment Risk List for
Boys (EARL-20B). Doctoral dissertation, Ontario Institute of Studies in Education, Toronto University, Canada.

Koegl, C. J. (2011). High-risk antisocial children: Predicting future criminal and health outcomes. Unpublished Doctoral dissertation, University of Cambridge, UK.

Koegl, C. J., Augimeri, L. K., Ferrante, P., Walsh, M. \& Slater, N. (2008). A Canadian programme for child delinquents. In R. Loeber, N. W. Slot, P. van der Laan \& M. Hoeve (Eds.), Tomorrow's criminals: The development of child delinquency and effective intervention (pp. 285-300). Aldershot: Ashgate.

Lahey, B., Moffitt, T. E. \& Caspi, A. (2003). The causes of conduct disorder and serious juvenile delinquency. New York: Guilford Press.

Levene, K. S., Augimeri, L. K., Pepler, D. J., Walsh, M. M., Koegl, C. J. \& Webster, C. D. (2001). Early Assessment Risk List for Girls: EARL-21G. Version 1. [Consultation edition]. Toronto, ON: Child Development Institute.

Levene, K. S., Walsh, M. M., Augimeri, L. K. \& Pepler, D. (2004). Linking identification and treatment of early risk factors for female delinquency. In $\mathrm{M}$. Moretti, C. Odgers \& M. Jackson (Eds.), Girls and aggression: Contributing factors and intervention principles (Vol. 19, pp. 147-164). New York: Kluwer Academic/Plenum Publishers.

Lipman, E. L., Bennett, K. J., Racine, Y. A., Mazumdar, R. \& Offord, D. R. (1998). What does early antisocial behaviour predict? A follow-up of 4- and 5-year-olds from the Ontario Child Health Study. Canadian Journal of Psychiatry, 43(6), 605-613.

Loeber, R., Farrington, D. P. \& Petechuk, D. (2003). Child delinquency: Early intervention and prevention. Washington, DC: U.S. Department of Justice, Office of Justice Programs, Office of Juvenile Justice and Delinquency Prevention.

Loeber, R., Slot, N. W. \& Stouthamer-Loeber, M. (2008). A cumulative developmental model of risk and promotive factors. In R. Loeber, N. W. Slot, P. H. Laan \& M. Hoeve (Eds.), Tomorrow's criminals. The development of child delinquency and effective interventions (pp. 133-161). Farnham: Ashgate. 
Moffitt, T. E. (1993). Life-course persistent and adolescent-limited antisocial behavior: A developmental taxonomy. Psychological Review, 100(4), 674-701.

Moffitt, T. E, Caspi, A., Rutter, M. \& Silva, P. A. (2001). Sex differences in antisocial behaviour: Conduct disorder, delinquency, and violence in the Dunedin longitudinal study. Cambridge: Cambridge University Press.

Odgers, C. L., Caspi, A., Broadbent, J. M., Dickson, N., Hancox, R. J., Harrington, H., et al. (2007). Prediction of differential adult health burden by conduct problem subtypes in males. Archives of General Psychiatry, 64(4), 476-484.

Snyder, H. N., Espiritu, R. C., Huizinga, D., Loeber, R. $\&$ Petechuck, D. (2003, March). Prevalence and development of child delinquency. Child Delinquency Bulletin Series (NCJ 193411). Washington,
DC: U.S. Department of Justice, Office of Juvenile Justice and Delinquency Prevention.

Walsh, M., Yuile, A., Jiang, D., Augimeri, L. K. \& Pepler, D. (2007). Early Assessment Risk List for Girls (EARL-21G): Predicting antisocial behaviours and clinical implications. Manuscript in preparation.

Webster, C. D., Douglas, K. S., Eaves, D. \& Hart, S. D. (1997). HCR-20: Assessing Risk for Violence. Version 2. Burnaby, British Columbia: Mental Health, Law $\&$ Policy Institute/Simon Fraser University.

Webster, C. D., Martin, M. L., Brink, J., Nicholls, T. L. \& Middleton, C. (2004). Manual for the ShortTerm Assessment of Risk and Treatability (START). Version 1.0. [Consultation edition]. Hamilton, Ontario: St. Joseph's Healthcare; Port Coquitlam, British Columbia: Forensic Psychiatric Services Commission. 